Reprod. Nutr. Dévelop., 1988, 28 (2 B), 365-374.

\title{
Timing the breeding season of the ewe : what is the role of daylength?
}

\author{
Jane E. ROBINSON, F. J. KARSCH (*)
}

AFRC Institute of Animal Physiology and Genetics Research, Babraham, Cambridge CB2 4AT, England

(*) Consortium for Research in Developmental and Reproductive Biology and Department of Physiology,

The University of Michigan, Ann Arbor, Michigan 48109-0404, USA.

Summary. Photoperiod is the proximate cue which times the reproductive period of the sheep and the role of daylength as a "zeitgeber " is evaluated in this report. Although sheep are regarded as a short-day breeding species, the reproductive period of the Suffolk ewe begins on daylengths which are on average 2.5 hours longer than those on which it ends. The reasons for this apparent anomaly are considered. Experimental evidence is presented which demonstrates that the transitions between the breeding season and anoestrus are not actively generated by changing ambient photoperiod. Rather the ewe expresses an endogenous circannual rhythm of reproduction and the role of daylength is to entrain this reproductive rhythm to a period of 365 days. It appears that only portions of the annual cycle of photoperiod are necessary to synchronise the breeding season, however, additional photic cues may be required to produce a reproductive period of normal duration.

\section{Introduction.}

The sheep is generally regarded as a "short-day " breeding species for two reasons. Firstly, the annual period of reproduction begins in late summer as the daylength is becoming shorter and terminates in late winter as daylength is gradually lengthening (Yeates, 1949; Hafez, 1952). Secondly, under artificial photoperiodic conditions, short days can induce a period of reproduction while long days inhibit the process (Mauléon and Rougeot, 1962 ; Legan and Karsch, 1980 ; Lincoln and Short, 1980). It might be assumed that the breeding season begins because shortening natural daylengths actively promote reproduction and ends because lengthening days actively inhibit the process. The present report questions this assumption and reconsiders the role of daylength in the timing of the annual breeding season of the ewe.

\section{Asymmetry between annual cycles of breeding and daylength.}

The importance of daylength cues for the appropriate timing of reproduction has been appreciated for half a century (Rowan, 1926) and it might seem logical 
for photoperiodic species to commence breeding when a certain threshold photoperiod has been attained and cease when the same photoperiodic threshold has been regained. However, reports of vertebrate breeding seasons which are symmetrical with respect to the annual photoperiodic cycle are rare. The sheep is no exception with the annual reproductive period being markedly skewed in relation to the photoperiodic cycle (Robinson and Karsch, 1984). This asymmetry is illustrated in figure 1 which depicts the timing of the transitions into and out of the breeding season in a flock of Suffolk ewes under natural conditions at Ann Arbor, Michigan over an eight year period.

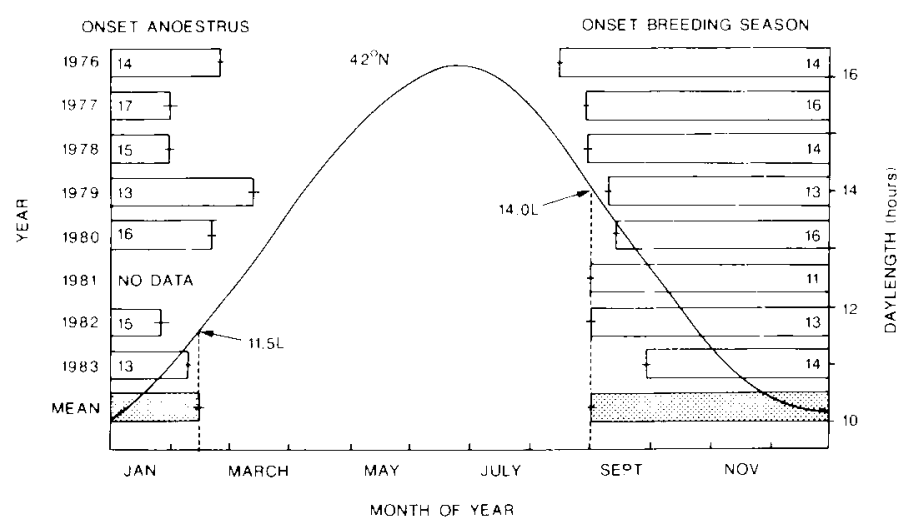

FIG. 1. - Asymmetry between breeding season and photoperiod. The timing of the breeding season of ovary intact Suffolk ewes is depicted for an 8-year period (1976 to 1983). Numbers in bars indicate the number of animals in each determination of the mean date $( \pm$ SEM) of the onset of the breeding season and of anoestrus. The mean dates $( \pm$ SEM) of the reproductive transitions over the 8 years are represented by the stippled bar (bottom). The annual cycle in photoperiod at $42^{\circ} \mathrm{N}$ is shown as the solid curve. (From Robinson and Karsch, 1984.)

On average, breeding began on 3 September $(74$ days after the summer solstice) when the daylength had decreased from $16.25 \mathrm{~L}$ to $14.0 \mathrm{~L}$ and ceased on 15 February ( 56 days after the winter solstice) when daylength had increased from $10.0 \mathrm{~L}$ to $11.5 \mathrm{~L}$. These observations are rather perplexing. Why should oestrous cyclicity in this "short day " species begin on daylengths which are actually 2.5 hours longer than those on which it ceases ?

The critical assumption inherent in the earlier paragraphs is that transitions between breeding and non-breeding conditions are generated by changing ambient daylength. Thus, the ewe is envisioned as being actively " driven " into the breeding season by short or shortening photoperiods and out of breeding by long or lengthening daylengths. Although experiments with abrupt changes in artificial daylength show unequivocally that reproductive transitions can be generated in this way, whether this happens in natural photoperiodic conditions is uncertain. Specifically, there are examples of "long day " breeding birds which cease reproductive activity even though days are still lengthening (Marshall and Coombs, 1957; Hamner, 1968; Jallageas, Tamisier and Assenmacher, 1978). 
These species obviously do not cease breeding because they are reproductively inhibited by short or even shortening daylengths. Further, several rodent species begin to breed because they have become insensitive to the formerly inhibitory actions of short days, rather than being reproductively induced by long or increasing daylengths (Reiter, 1972; Turek et al., 1975). In the ewe, the lack of symmetry between the annual breeding and photoperiodic cycles could be explained if one, or both, of the reproductive transitions occurred spontaneously rather than being generated by changing daylength. Thus, we determined whether breeding is initiated in natural conditions by the shortening daylengths of late summer and terminated by the lengthening photoperiods of late winter. The following study considers the photic cues which time the onset of the reproductive period. Specifically, we sought to answer this question :

\section{Does the ewe need to perceive the decreasing daylengths of late summer to initiate breeding at the appropriate time of year?}

The design of the experiment is shown in the left panel of figure 2 ; a full account of the study can be found in Robinson, Wayne and Karsch (1985). Prior to the experiment, 18 ewes were maintained on natural photocycle. On the summer solstice, these were assigned to one of three treatment groups. Six ewes (Natural group) remained in natural photoperiods outdoors while the remaining 12 were moved indoors and placed on artificial daylengths. Half of these were maintained on the summer solstice photoperiod of 16.25 hours of light per day (Solstice Hold group, $n=6$ ), while the other half were exposed to stepwise decrements in

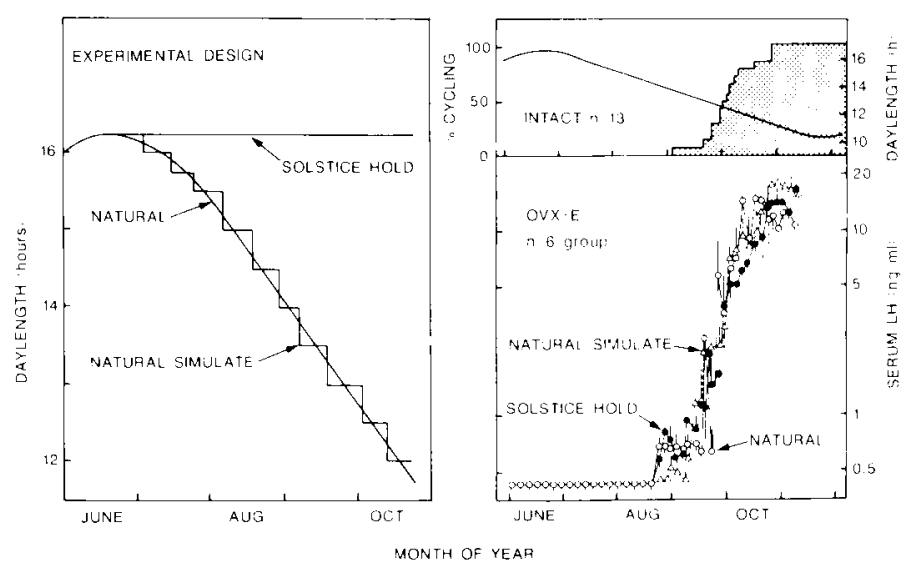

FIG. 2. - Left : Experimental design. Daylength to which 3 groups of OVX $+E$ ewes were exposed between June and October 1983. Right, top: Time of onset of the breeding season of the 13 ovary intact ewes (stippled area). Bottom : Mean ( \pm SEM) serum $L H$ levels in the three groups of $O V X+E$ ewes. $O=$ undetectable concentrations. (From Robinson, Wayne and Karsch, 1985.1 
daylength approximating the natural decline in daylengths of late summer (Natural Simulate group, $n=6$ ). The rationale behind this design is as follows; if ewes need to see declining photoperiods to initiate the breeding season at the appropriate time of year, then the group maintained on the solstice photoperiod should remain in anoestrus. All ewes were ovariectomised and implanted with constant release capsules of oestradiol (OVX $+E$ ). Reproductive condition was monitored by tracking the response to oestradiol negative feedback of $\mathrm{LH}$ secretion. Changes in serum LH provide a highly sensitive marker of reproductive function, concentrations being high in the breeding season and low in anoestrus (Legan, Karsch and Foster, 1977). Further, changes in response to oestradiol negative feedback in OVX $+E$ ewes are temporally correlated with changes in oestrous cyclicity in animals with intact ovaries (Legan and Karsch, 1980). To determine the time of onset of the breeding season in ovary intact ewes, a further group of 13 animals was maintained outdoors with the Natural group and oestrous cycles monitored with a raddled vasectomised ram.

The mean date of the first ovulation in these ewes was calculated to be 28 September \pm 3 days (see fig. 2, right). At this time, despite their radically different photoperiodic treatments, serum LH levels began to rise simultaneously in all three groups of OVX $+E$ ewes. Concentrations rose above $1 \mathrm{ng} / \mathrm{ml}$ on 30 September \pm 2 days (Natural), 2 October \pm 8 days (Natural Simulate) and 28 September \pm 5 days (Solstice Hold). Thereafter, mean LH concentrations did not differ among the three groups. Thus, it appears that the Suffolk ewe does not need to see the decreasing daylengths of late summer to initiate breeding at the appropriate time of year. Rather an endogenous predisposition to begin breeding is expressed. This also appears to be true of Dorset Horn and Welsh Mountain ewes (Worthy et al., 1985).

We also sought to establish the photic cues which cause breeding to cease and asked the following question :

\section{Does the ewe need to perceive the increasing daylengths of late winter in order to terminate breeding at the appropriate time of year?}

The design of this experiment is essentially similar to that of the previous study and is depicted in the left panel of figure 3. Further, details of this study can be found in Robinson and Karsch (1984). Eighteen ewes were ovariectomised on 30 November while on natural daylengths. Six of these remained outdoors throughout the experiment (Natural group), in the presence of rams and along with the cycling flock of 13 ovary intact ewes. On the winter solstice, the remaining 12 ewes were moved into an adjacent building (in which rams had never been present) and exposed to one of two light treatments. One group (Solstice Hold, $\mathrm{n}=6$ ) was maintained on the winter solstice photoperiod of $10 \mathrm{~h}$ of light per day while the other group (Natural Simulate, $n=6$ ) saw daylengths increasing stepwise to simulate the natural spring rise. We reasoned that if ewes need to see an increase in daylength to terminate breeding at the appropriate 
time, then the group remaining on the solstice photoperiod should remain in breeding condition. As in the previous experiment, reproductive status was assessed by measuring serum concentrations of $\mathrm{LH}$. The results of the study are depicted in the right panels of figure 3.

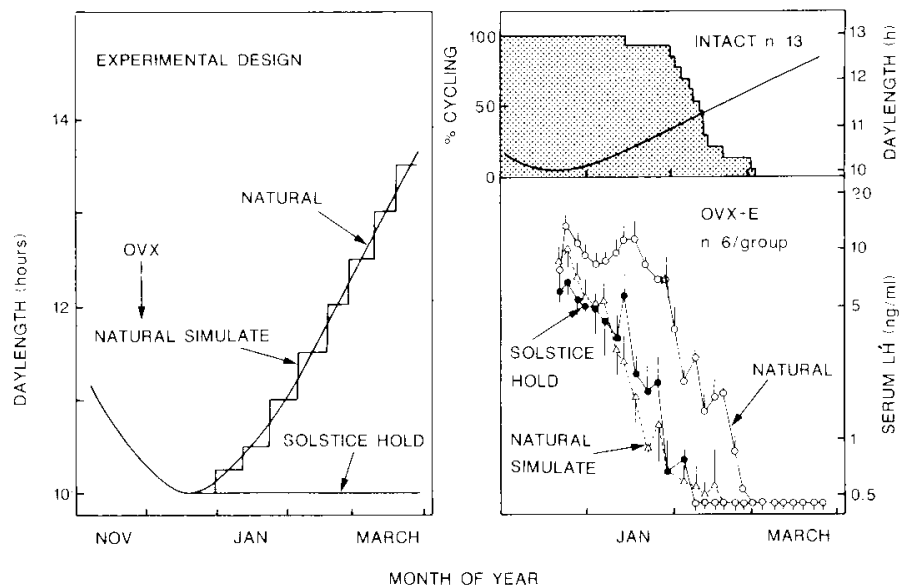

FIG. 3. - Left : Experimental design. Daylengths to which the 3 groups of OVX $+E$ ewes were exposed between November 1982 and March 1983. OVX denotes the time of ovariectomy. Right top : Time of the end of the breeding season in the 13 ovary intact ewes (stippled area). Bottom : Mean ( $\pm S E M)$ serum $L H$ concentrations in the 3 groups of OVX $+E$ ewes which saw the three different photoperiodic treatments. (From Robinson and Karsch, 1984.)

Oestrous cycles ceased in the ovary-intact ewes on 10 February \pm 3 days, at the time when there was a dramatic fall in gonadotrophin levels in the OVX $+E$ ewes of the Natural group. Concentrations of LH were consistently below $1 \mathrm{ng} / \mathrm{ml}$ after 18 February \pm 3 days. A similar precipitous decline in hormone levels occurred in the Natural Simulate and Solstice Hold groups, with levels falling below $1 \mathrm{ng} / \mathrm{ml}$ by 24 January \pm 5 and 26 January \pm 6 days, respectively. Thus, the breeding season of animals which never saw an increasing photoperiod was not extended. These data indicate that the ewe does not need to experience the lengthening days of late winter in order to cease breeding at the appropriate time of year ; rather an endogenous predisposition to terminate the breeding season is expressed (see also Worthy and Haresign, 1983). The fact that LH actually fell a couple of weeks earlier in the groups of ewes housed indoors may reflect differences in the proximity of rams, a factor which is known to influence the reproductive state of the ewe (Martin et al., 1983 ; Legan and Karsch, 1983).

\section{Circannual rhythms of reproduction.}

If daylength does not actively drive either of the reproductive transitions under natural photoperiodic conditions, then what role does photoperiod play to ensure that breeding is confined to the appropriate time of year? We have 
suggested that both reproductive transitions occur because the ewe has a predisposition to begin breeding in late summer and cease breeding in late winter. The inbuilt tendency for sheep to oscillate between periods of breeding and nonbreeding is illustrated by studies in which animals have been maintained for extended periods in an unchanging photoperiodic environment. Thus, animals which were blinded (Legan and Karsch, 1983), pinealectomised (Bittman et al., 1983 ; Karsch et al., 1986), or held in a constant daylength (Ducker, Bowman and Temple, 1973 ; Howles, Craignon and Haynes, 1982) continued to have cycles of breeding. Because the period of these cycles is close to (but not exactly) one year, they are termed circannual rhythms. With time, the oscillations between periods of reproductive activity and inactivity become desynchronised among individuals and out of phase with the annual reproductive cycle of animals maintained in natural daylength. Such endogenous circannual rhythms of reproduction have now been demonstrated in several classes of animals (Gwinner, 1987). Figure 4 (right) shows an example of the persisting reproductive rhythm of in ewe 2023 which was maintained on a constant short daylength for a 5-year period. This desynchronised rhythm is in contrast with that of ewe 002 (fig. 4, left) which was subject to the annual photoperiodic cycle outdoors (see legend for further details).

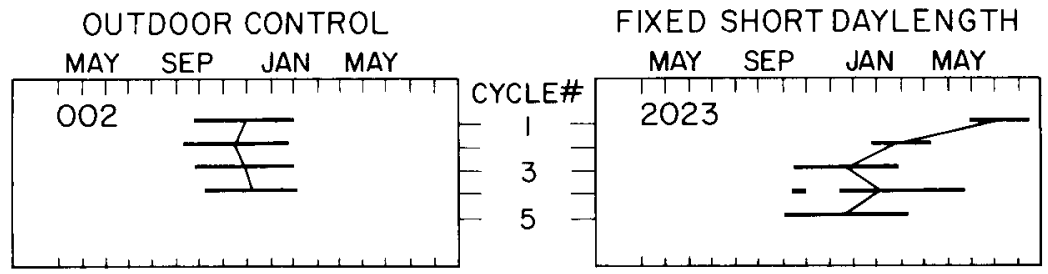

FIG. 4. - Rhythms of reproduction in two individual OVX + E ewes. Ewe 2023 (right) was maintained for 5 years on a fixed short daylength $(8 \mathrm{~L}: 16 \mathrm{D})$ while ewe 002 (left) was held on a natural photocycle outdoors. Horizontal bars indicate times when LH levels were above $1 \mathrm{ng} / \mathrm{ml}$. Lines linking these bars join the mid point of each reproductive period. Note the variability in the timing of the reproductive period of the ewe held in an unchanging daylength compared with the relative stability in its timing from year to year in the ewe which saw a natural photoperiodic cycle. (Karsch, Robinson, Woodfill and Brown, unpublished.)

Thus, it appears that the seasonal reproductive rhythm of the ewe, rather than being generated by daylength, is entrained to 365 days by the annual photoperiodic cycle.

\section{Entrainment of the circannual reproductive rhythm.}

In this section, we outline an experiment in which we have begun to examine the photoperiodic requirements for synchronising the endogenous reproductive rhythm of the ewe to a period of 365 days. Our earlier observations that shcep become unresponsive to the ambient photoperiod around the summer and winter 
solstires suggest that the entire annual photoperiodic cycle may not be necessary for entrainment. Our approach in testing this hypothesis was to render Suffolk ewes non-photoperiodic by pinealectomy and to restore blocks of daylength cues intermittently by infusion of physiological patterns of melatonin in an attempt to resynchronise the endogenous "free running " reproductive rhythm. The experimental design is shown in figure 5.
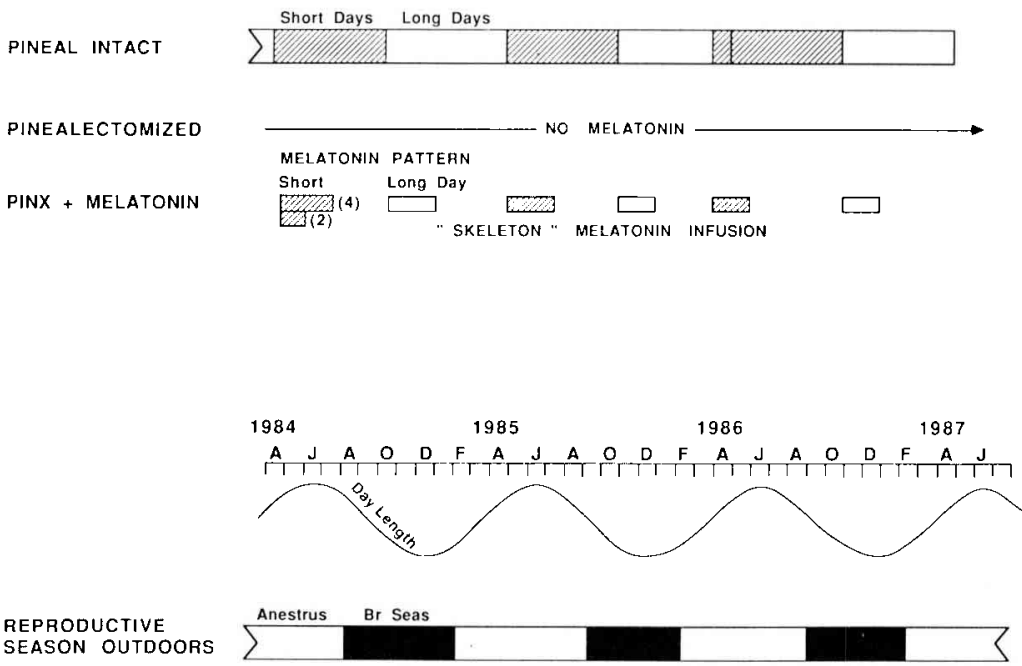

FIG. 5. - Experimental design. Photoperiodic and melatonin treatments to which OVX $+\mathrm{E}$ ewes were exposed over a 3-year period from 1984 to 1987. See text for further details. (Karsch, Robinson, Malpaux, Wayne and Brown, unpublished.)

Two groups of ewes were pinealectomised and maintained indoors in the absence of rams. One group received no melatonin (Pinealectomised) while the other (PINX + Melatonin) was infused for three years with a "skeleton 》 melatonin infusion. This consisted of 70 days of a melatonin pattern which mimicked that secreted on short days (16 hr infusion ; $8 \mathrm{~L}: 16 \mathrm{D}$ ) and 70 days of infusion of a long-day pattern of melatonin ( $8 \mathrm{hr}$ infusion ; $16 \mathrm{~L}: 8 \mathrm{D}$ ). The longand short-day patterns of melatonin were spaced 6 months apart and positioned approximately 6 months out of phase with the natural photocycle. No melatonin was given at other times. A group of pineal-intact control ewes was maintained indoors on artificial photoperiods alternating between 6 months of short and long days. The timing of the reproductive rhythm of these ewes was compared to that of a group of outdoor pineal-intact controls to determine whether the photoperiodic reversal caused a $180^{\circ}$ phase shift in the annual reproductive rhythm. All animals were OVX $+E$ and reproductive state was monitored by $\mathrm{LH}$. Levels consistently above $1 \mathrm{ng} / \mathrm{ml}$ were considered to be indicative of reproductive induction (Robinson and Karsch, 1984; Robinson, Wayne and Karsch, 1985 ; Robinson, Radford and Karsch, 1985). 
The reproductive period in the control ewes maintained outdoors began between late August and late September in the 3 years of the study. The average interval between successive onsets of reproduction was 361 days. The time of onset of the reproductive period in the pineal-intact controls housed in artificial daylengths was late April, predictably some 6 months out of phase with that in animals maintained outdoors. The period length in this phase-shifted cycle was close to one year, being 361 days. Pinealectomy abolished the ability of photoperiod to synchronise the cycles of LH secretion. Although long-term fluctuations in LH were still present, they were asynchronous among animals and occurred at random times with respect to the seasonal cycle in control ewes maintained outdoors. In marked contrast, all pinealectomised ewes receiving the " skeleton " melatonin infusion displayed regular, high amplitude cycles in LH secretion. The date of $\mathrm{LH}$ rise was remarkably consistent from year to year (1985, 1 March \pm 2 days ; 1986, 3 March \pm 2 days ; 1987, 2 March \pm 2 days). This results in an average period length of 366 days. These observations demonstrate that the endogenous rhythm of reproductive neuroendocrine activity in the ewe can be phase shifted and synchronised to a period of one year by an infusion of melatonin for only two segments of the year. This finding immediately leads to further questions. For example, would only one exposure to photic cues be sufficient for entrainment, as it is with circadian rhythms ? What is the length of exposure to melatonin necessary for synchronisation? One further interesting observation to emerge from this study concerns the length of the LH elevation produced by the "skeleton " melatonin infusion. This was about $50 \%$ shorter than that in ewes maintained outdoors. Thus, our melatonin treatment, although sufficient for entrainment, was unable to produce a breeding season of normal duration. Perhaps additional photic cues are needed to fulfill this role?

\section{Conclusions.}

Although there are still many questions to which we have no answers, we are gaining insight into the photoperiodic cues which time the annual breeding season of the Suffolk ewe. Specifically, the transitions between breeding and anoestrous conditions are not generated by changing ambient daylength. Rather, ewes possess an endogenous circannual rhythm of reproduction which is entrained to 365 days by the annual photoperiodic cycle. Only a portion of the daylength cycle is necessary to synchronise the reproductive rhythm; more extensive photic cues may be essential for producing a breeding season of normal duration. 
Acknowledgements. - We wish to thank Douglas Doop, Barbara Glover and Andrew Cochrane for their technical assistance. The Standards and Reagents Core Facility prepared reagents for the LH assay and the Sheep Research Core Facility maintained the ewes. Artwork was carefully prepared by Richard Bunting and the manuscript typed by Jennifer Cummings. The research was supported by grants from NIH (HD-18337 and HD-18258) NSF (PCM-8316364) and The Ford Foundation.

Résumé. Contrôle de la saison de reproduction chez la Brebis : quel est le rôle de la durée du jour?

La photopériode est le principal facteur qui détermine la saison de reproduction chez le mouton. Le rôle de la durée du jour agissant comme "zeitgeber " est étudié dans cet article. Bien que le mouton soit considéré comme un animal se reproduisant en jours courts, la période de reproduction de la brebis Suffolk débute lorsque la durée du jour est en moyenne $2,5 \mathrm{~h}$ plus longue que celle durant laquelle elle se termine. Les raisons de cette contradiction apparente sont étudiées. Les résultats expérimentaux démontrent que le passage de la saison sexuelle à la période d'anestrus n'est pas réellement provoqué par le changement de la photopériode. II semble plutôt que la brebis exprime un rythme circannuel endogène et le rôle de la durée du jour est d'entraîner ce rythme de reproduction sur une période de 365 jours. II apparaît que seulement des portions du cycle annuel de photopériode sont nécessaires à la synchronisation de la saison de reproduction. Cependant, d'autres informations photiques peuvent être nécessaires pour une durée normale de la période de reproduction.

\section{References}

BITTMAN E. L., KARSCH F. J., HOPKINS J. W., 1983. Role of the pineal gland in ovine photoperiodism : regulation of seasonal breeding and negative feedback effects of estradiol upon luteinizing hormone secretion. Endocrinology, 113, 329-336.

DUCKER M. J., BOWMAN J. E., TEMPLE A., 1973. The effect of constant photoperiod on the expression of oestrus in the ewe. J. Reprod. Fertil., Suppl. 19, 143-150.

GWINNER E., 1986. Circannual rhythms. Springer-Verlag, Berlin.

HAFEZ E. S. E., 1952. Studies on the breeding season and reproduction of the ewe. J. agric. Sci, 42, $189-265$.

HAMNER W. H., 1968. The photorefractory period of the house finch. Ecology, 49, 211-227.

HOWLES C. M., CRAIGON J., HAYNES N. B., 1982. Long-term rhythms of testicular volume and plasma prolactin concentrations in rams reared for 3 years in constant photoperiod. $J$. Reprod. Fertil., 65, 439-446.

JALLAGEAS M., TAMISIER A., ASSENMACHER I., 1978. A comparative study of the annual cycles in sexual and thyroid function in male Pekin ducks (Anas platyrhynchos) and teal (Anas crecca). Gen. comp. Endocr., 36, 201-210.

KARSCH F. J., ROBINSON J. E., WAYNE N. L., MALPAUX B., 1986. Melatonin entrainment of an endogenous reproductive rhythm in the ewe. Annu. Meet. Soc. Study Fertil. (Abstr. 127).

LEGAN S. J., KARSCH F. J., 1980. Photoperiodic control of seasonal breeding in ewes : modulation of the negative feedback action of estradiol. Biol. Reprod., 23, 1061-1068.

LEGAN S. J., KARSCH F. J., 1983. Importance of retinal photoreceptors to the photoperiodic control of seasonal breeding in the ewe. Biol. Reprod., 29, 316-325.

LEGAN S. J., KARSCH F. J., FOSTER D. L., 1977. The endocrine control of seasonal reproductive function in the ewe : a marked change in response to the negative feedback action of estradiol on luteinizing hormone secretion. Endocrinology, 101, 818-824. 
LINCOLN G. A., SHORT R. V., 1980. Seasonal breeding : nature's contraceptive. Recent Prog. Horm. Res., 36, 1-52.

MARSHALL A. J., COOMBS C. J. F., 1957. The interaction of environmental, internal and behavioural factors in the rook (Corvus $f$. frugilegus). Proc. Zool. Soc. Lond., 128, 545-589.

MARTIN G. B., SCARAMUZZI R. J., LINDSAY D. R., 1983. Effect of the introduction of rams during the anoestrous season on the pulsatile secretion of LH in ovariectomised ewes. $J$. Reprod. Fertil., 67, 47-55.

MAULÉON P., ROUGEOT J., 1962. Régulation des saisons sexuelles chez des brebis de races différentes au moyen de divers rythmes lumineux. Ann. Biol. anim. Bioch. Biophys., 2, 209-222.

REITER R. J., 1972. Evidence for refractoriness of the pituitary gonadal axis to the pineal gland in golden hamsters and its possible implications in annual reproductive rhythms. Anat. Rec., 173, 365-371.

ROBINSON J. E., KARSCH F. J., 1984. Refractoriness to inductive day lengths terminates the breeding season of the Suffolk ewe. Biol. Reprod., 31, 656-663.

ROBINSON J. E., RADFORD H. M., KARSCH F. J., 1985. Seasonal changes in pulsatile luteinizing hormone (LH) secretion in the ewe : relationship of LH pulses to day length and response to estradiol negative feedback. Biol. Reprod., 33, 324-334.

ROBINSON J. E., WAYNE N. L., KARSCH F. J., 1985. Refractoriness to inhibitory day lengths initiates the breeding season of the Suffolk ewe. Biol. Reprod., 32, 1024-1030.

ROWAN W., 1926. Experiments in bird migration. 1. Manipulation of the reproductive cycle : seasonal histological changes in the gonads. Proc. Boston Soc. Nat. Hist., 39, 151-208.

TUREK F. W., ELLIOTT J. A., ALVIS J. D., MENAKER M., 1975. Effect of prolonged exposure to nonstimulatory photoperiods on the activity of the neuroendocrine-testicular axis of golden hamsters. Biol. Reprod., 13, 475-481.

WORTHY K., HARESIGN W., 1983. Evidence that the onset of seasonal anoestrus in the ewe may be independent of increasing prolactin concentrations and daylength. J. Reprod. Fertil, 67. 465-471.

WORTHY K., HARESIGN W., DODSON S., MCLEOD, B. J., FOXCROFT G. R., HAYNES N. B., 1985. Evidence that the onset of the breeding season in the ewe may be independent of decreasing plasma prolactin concentrations. J. Reprod. Fertil., 75, 237-246.

YEATES N. T. M., 1949. The breeding season of the sheep with particular reference to its modification by artificial means using light. J. agric. Sci, 39, 1-43. 